Ann. Parasitol. Hum. Comp., 1993, $68: \mathrm{n}^{\circ} 3,121-124$.

Mémoire.
Key-words: S. haematobium. Eggs. Human ureters. Fibroblasts. Plasma cells. Macrophages. Multinucleated giant cells. Electron microscopy.

Mots-clés : S. haematobium. OEufs. Uretères humaines. Fibroblastes. Plasmocytes. Macrophages. Cellules géantes. Microscopie électronique.

\title{
HUMAN BILHARZIAL URETERS II. CELLULAR DYNAMIC AGAINST DEPOSITED EGgS
}

\author{
SAMIR M. EL-SHOURA
}

\begin{abstract}
SUMMARY
The cellular dynamic against deposited Schistosoma haematobium eggs was studied in the submucosa and muscularis of the lower ureteral segments of Saudi patients with chronic urinary schistosomiasis. This dynamic activity was greatly affected by the damaged phase of the egg embryo. Freshly deposited eggs with " healthy » embryos were entirely surrounded by long cytoplasmic extensions of fibroblasts. Eggs with partially damaged embryos were surrounded by plasma cells which were focally adhered to spines of egg-shells and releasing their granular contents over their surface. Eggs with « dead » embryos, or empty egg-shells, were
\end{abstract}

surrounded by actively mobile macrophages possessing numerous lysosomes, phagocytic vacuoles, and convoluted surface projections. After " peeling " off the outer and intermediate shell layers, macrophages invaded into eggs and fused together forming multinucleate giant macrophages. This study showed that the fibroblastic extensions acted as barriers between the parasite eggs or their products, and the host tissue; the plasma cell secretion over the egg surface may be involved in the migration of macrophages towards deposited eggs; and macrophages were the only dynamic cells responsible for the egg-shell invasion possibly for elimination.

\section{RÉsumé : L'uretère dans la bilharziose urinaire. II. Dynamique cellulaire contre les œufs.}

La dynamique cellulaire engendrée par la présence de Schistosoma haematobium a été étudiée dans la sous-muqueuse et la muqueuse des segments inférieurs de l'uretère chez des malades d'Arabie Saoudite ayant une schistosomiase urinaire chronique. Cette dynamique est déclenchée surtout par l'œuf embryonné en cours de destruction. Les œufs récemment déposés avec des embryons sains sont entourés complètement par de longues expansions cytoplasmiques des fibroblastes. Les œufs avec des embryons altérés sont entourés par des plasmocytes qui adhèrent à leur surface. Les œufs à embryons morts ou les œufs vides sont entourés par des macrophages libres possédant de nombreux lysosomes, des vacuoles phagocytaires et, en surface des reliefs enchevêtrés. Après destruction des couches ovulaires externes et intermédiaires, les macrophages envahissent l'œuf et fusionnent pour former des cellules géantes multinucléées.

L'étude montre que les extensions fibroblastiques ont un rôle de barrière entre les œufs parasités et leurs sécrétions, et les tissus de l'hôte. La sécrétion des plasmocytes sur la surface de l'œuf peut avoir un rôle dans la migration des macrophages vers les œufs; les macrophages sont les seules cellules dynamiques responsables de l'invasion de la coque ovulaire et probablement de leur destruction.

\section{INTRODUCTION}

In Schistosoma haematobium infections, eggs are trapped in walls of the urinary bladder and lower ureteral segments. Secretion products of the egg's larvae (miracidia) generate an immunologic granuloma that heals by fibrosis (Andrade, 1963). These parasite products sensitize the host lymphocytes which migrate to areas of egg deposition and recruit other cells including neutrophilic and eosinophilic granulocytes, monocytes and macrophages, and fibroblasts, in addition to mast cells and blood platelets (El Shoura et al., 1993). This cell aggregation is largely due to a T-cell mediated

Department of Pathology, College of Medicine, King Saud University, Abha P. O. Box 641, Saudi Arabia.

Accepté le : 26 janvier 1993. immune response of the host against soluble antigenic components produced by the miracidium (Bentley et al., 1982; Phillips and Lammie, 1986). In addition, there is extensive differentiations of lymphocytes to plasma cells and macrophages into epithelial, fibroblastic and multinucleated giant cells (Melro and Mariano, 1987; Godoy et al., 1982; Papadimitriou and Ashman, 1989). However, the role of these various cell types in elimination of Schistosoma eggs is not fully understood.

Herein, the morphological mechanism of adherence to and invasion into the parasite eggs by certain granuloma cells is described at the transmission electron microscopy (TEM) level, focussing particularly upon the dynamic interaction between host leucocytes and parasite eggs to understand the magnitude of host tissue destruction and the egg elimination. 


\section{MATERIALS AND METHODS}

Biopsies from lower segments of dilated ureters were obtained from seven Saudi patients, aged 26-63 (mean 38.5) with long history of urinary schistosomiasis. Each specimen was cut into $2-3 \mathrm{~mm}^{3}$, and immediately fixed in $2.5 \%$ glutaraldehyde in $0.1 \mathrm{M}$ sodium cacodylate buffer, $\mathrm{pH} 7.2$ at $4^{\circ}$ for $2-3 \mathrm{~h}$. Specimens were decalcified in $1 \%$ EDTA for 5 days. Samples were postfixed in $1 \%$ osmium tetroxide, dehydrated in an ascending series of ethyl alcohol, and embedded in Spurr's resin. Semithin sections (0.5 Um) were stained with toluidine blue. Ultrathin sections were stained with uranyl acetate and lead citrate and examined in a Jeol 1200 EX TEM.

\section{RESULTS}

At the light microscopy level (Fig. 1), the semithin sections showed many deposited, well and partially preserved eggs scattered in the submucosa. A few of these eggs were also trapped among the muscle layers. Several eggs were partially calcified and were surrounded by variable number and types of granuloma forming cells. These were accumulated from either the surrounding blood vessels or the base of the epithelium downward where a richly vascularized granulation tissue was diffusely infiltrated by a massive number of these cells.

At the TEM level, cross sections of several freshly deposited eggs with " healthy » looking embryonic tissues were entirely encircled by very long, thin cytoplasmic extensions arised from fibroblastic cells (Fig. 2). Their cytoplasm contained well developed cisternae of rough endoplasmic reticulum (RER), vacuoles, and membrane-bound granules of various densities, in addition to pinocytic pits and vesicles beneath the cell surface (Fig. 3). There was always a space filled by an intermediate dense material separating the eggshell from the cell body and its extensions, this space is almost defined by the length of egg spines (Figs. 2, 3). A calcified zone between the fibroblast surrounding the egg and the host tissue was frequently observed (Fig. 2).

In eggs with partially damaged embryos, mature plasma cells were focally adhered to spines of the egg-shell (Figs. 4, 5). These cells were characterized by eccentric nucleus and cytoplasm filled with whorls of well developed cisternae of RER. The cell granular contents were being released over the egg surface (Figs. 6, 7).

Eggs with " dead » embryos, or empty egg-shells were either surrounded by or enclosing highly active macrophages (Figs. 8-12). The embryo was identified as "dead " when its entire tissues were necrotic. The mechanism of egg invasion by host macrophages was observed. Macrophages containing numerous lysosomes and phagocytic vacuoles were first attached to eggs whose surfaces were covered by a moderately dense material (Fig. 8) similar to that released by plasma cell granular contents (Figs. 6, 7). They then flatten over the egg-shell in close apposition to the surface spines (Fig. 9). Some other large macrophages with cha-
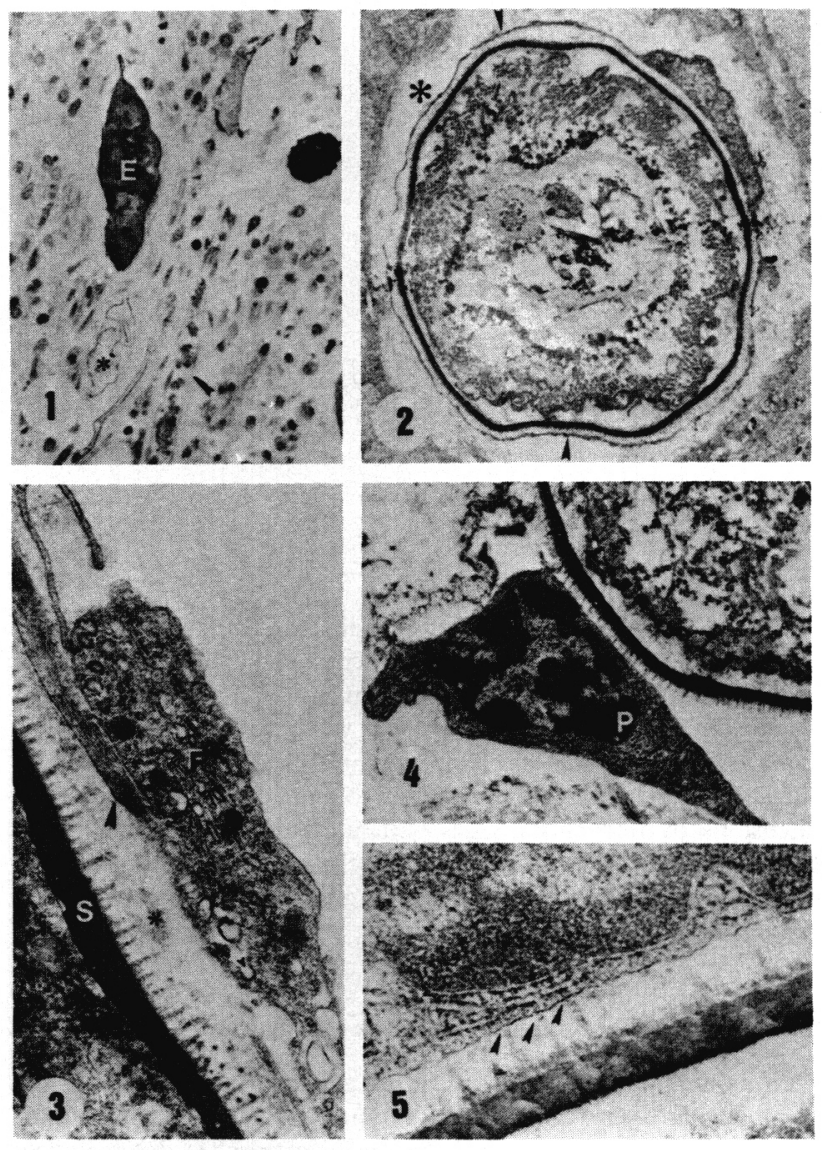

FIG. 1. - Semithin section showing a freshly deposited egg (E) with a « healthy » looking embryo and an empty egg-shell (*). Arrowhead points to a blood capillary. $\times 800$.

Fig. 2. - Transverse section through a freshly deposited egg encircled by fibroblastic extensions (arrowheads). Asterisk represents a calcified area. $\times 5,000$.

Fig. 3. - A fibroblast (F) with long extension (arrowhead) in close vicinity to the egg-shell (S). Note the secretion $\left({ }^{*}\right)$ between the cell and the shell. Small arrowhead points to a submembranous pinocytic pit. $\times 37,500$.

FIG. 4. - A mature plasma cell (P) focally adhered to an egg with partially damaged embryo. $\times 12,500$.

Fig. 5. - High magnification of Fig. 4 showing adherence (arrowheads) between the plasma cell and the shell spines. $\times 62,500$.

racteristic features of highly mobile and actively phagocytic cells indicated by long, irregularly convoluted surface projections (Fig. 10), were also adhered to the egg surface via their projection facing the nuclear pole (Fig. 10). This step was possibly taken place prior to the macrophage to be flatten over the egg-shell. Invasions into egg-shells occurred after "peeling " off the outer and middle shell layers (Fig. 11). Hence, the macrophage became in direct contact with the underlying vitelline membrane (Fig. 11). Within the egg-shell, these macrophages may fuse together to form multinucleated giant cells (Figs. 12, 13), bearing the same ultrastructural features of macrophages. 

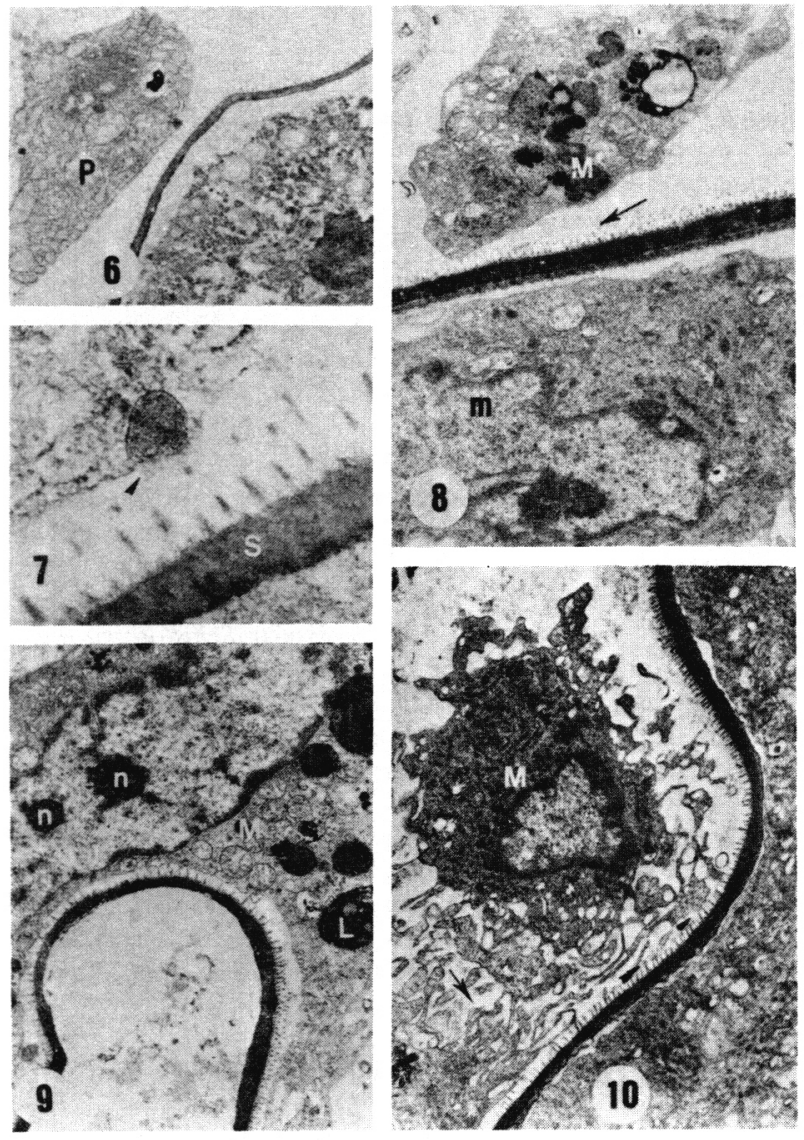

FIG. 6. - A plasma cell (P) with secretory granules in close vicinity to an egg with partially damaged embryo. $\times 7,500$.

Fig. 7. - High magnification of Fig. 6 showing the release of granular contents (arrowhead) over the shell (S) surface. $\times 30,000$.

FIG. 8. - A macrophage (M) externally associated to an egg-shell enclosing another macrophage $(\mathrm{m})$. Arrow points to a secretion on the shell surface. $\times 15,000$.

Fig. 9. - A macrophage (M) flatten over the egg-shell and closely apposed to the shell spines. L, lysosomes; $n$, macrophage nucleoli. $\times 12,500$.

FIG. 10. - A macrophage (M) with extremely convoluted surface projections (arrow), some of which adhered to the egg surface (arrowheads). $\times 12,500$.

\section{DISCUSSION}

Observations by TEM presented here confirmed that the concentrically arranged cell population in the schistosome egg granuloma changes with time and with the dying off miracidium. Eggs with " healthy " looking embryos were tightly encircled by long fibroblastic extensions; these apparently acted as barriers between the parasite eggs or their products and the host tissue. The moderately dense material enclosed between the egg surface and the fibroblastic extensions could be derived from either the egg or the granuloma cells or both. This material is suggested to be the

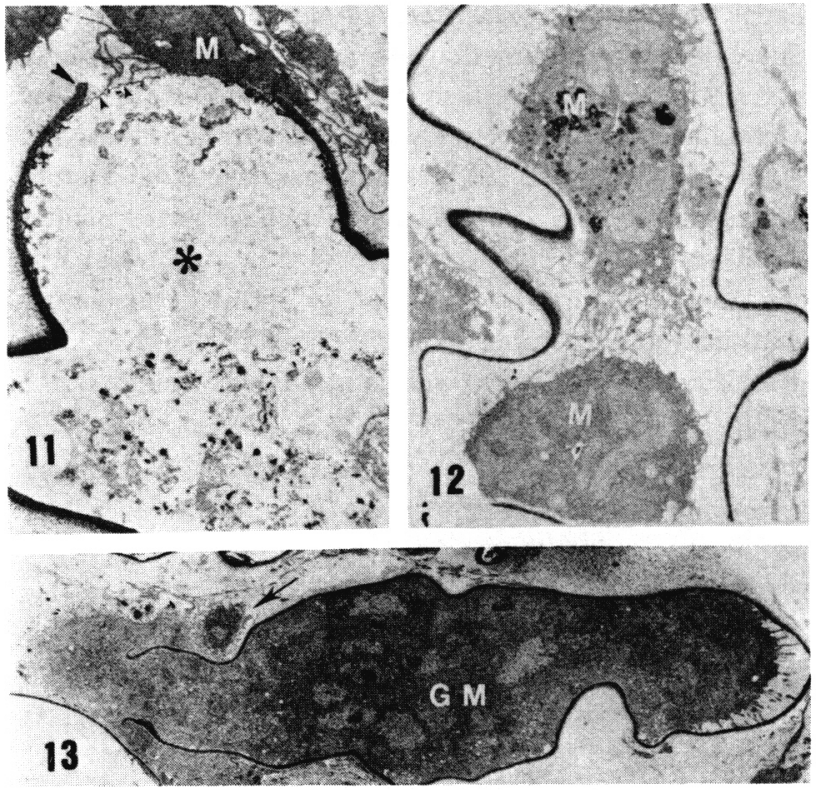

Fig. 11. - A macrophage (M) in direct contact to the underlying vitelline membrane (small arrowheads) of an empty egg $\left({ }^{*}\right)$ after « peeling » off the outer and middle egg-shell layers (large arrowhead). $\times 7,500$.

Fig. 12. - Two macrophages (M) within an empty egg-shell before fusion. $\times 5,000$.

Fig. 13. - A multinucleated giant macrophage (GM) within an egg-shell. Arrow points to an outer macrophage. $\times 7,500$.

functional interface between the host and parasite, and is possibly responsible for the egg lesion.

Several mature plasma cells were adhered to and release their granular secretion on the egg surface. This secretion may be involved in the migration of macrophages towards deposited eggs. The significance of antibody-producing plasma cells in egg granuloma formation is not clear. Plasma cells occur in significant numbers in vivo as well as in vitro (Smith, 1977; Bentley et al., 1982). Their ability to produce antibody against $S$. mansoni antigens has been demonstrated in vivo (von Lichtenberg, 1964). However, it has been documented that the appearance of cell-mediated reactions is characterized by the presence of mononuclear cells whilst the presence of plasma cells is indicative of an antibody-mediated response (Smith, 1977).

The present study also showed that human macrophages are the most dynamic cells in the egg granuloma and are the only cells responsible for the egg invasion. In in vivo studies (Kassis et al., 1979), eosinophils and macrophages were observed adhering to the schistosomula surface, while macrophages only were shown invading the disrupted surface of the parasite. The mechanism of schistosome killing by lymphokine-activated macrophages remains uncertain. However, a genetic correlation between macrophage activation for killing of schistosomula and activation for tumo- 
ricidal function has been observed (Skameen et al., 1984; James, 1986), suggesting that the cytotoxic mechanism may be similar. It has also been shown that lymphokine-activated macrophages can elaborate a soluble protein of a lysosomal origin (Malkin et al., 1987), which has larvacidal factors (James and Claven, 1987). This macrophage protein could also have a killing effect on the egg embryo. Several studies have dealt with the nature of the cytotoxic mediators which activated macrophages may be used during the killing of schistosomula in vitro (Olds et al., 1980; Malkin et al., 1987).

The multinucleated giant cells (MGCs) seen enclosed within empty egg-shells appear to be a further developmental phase of the activated macrophages resulting from cellular fusion (Murch et al., 1982). The mechanism of this fusion is not clear, although lymphokines are known to be involved (Postlethwaite et al., 1982). However, the exact role of MGCs in the destruction of schistosome eggs is uncertain. These cells are known to be actively pinocytic, but their phagocytic performance is less than that of exudate macrophages (Papadimitriou et al., 1975).

Acknowledgments. - $\mathrm{D}^{\mathrm{r}} \mathrm{S}$. SHETTY, Department of Urology, College of Medicine, King Saud University, Abha, is greatly appreciated for providing ureteral biopsies infected with schistosome eggs.

\section{REFERENCES}

Andrade Z. A. : Hepatic schistosomiasis. Morphological aspects. In: H. Popper, F. Schaffiner (Eds.). Progress in liver disease. Grune and Stratton, New York, Vol. II, 1963, 228-242.

Bentley A. G., Doughty B. L., Phillips S. M. : Ultrastructural analysis of the cellular response to Schistosoma mansoni. III. The in vitro granuloma. Am. J. Trop. Med. Hyg., 1982, 31, 1168-1180.

El-Shoura S. M., Ramadan N. F., Hassouna O., Mahmoud H. I., Shetty S., Westmuckett A. D. : Human bilharzial ureters: I. Fine structure of eggs deposited in the submucosa and muscularis. Afr. J. Med. Medical Sci. (In Press).

Godoy M., Geuskens M., Van Mark E. A. E., Borojevic R., Van Gensen P. : Schistosomiasis and in vitro transdifferentiation of murine peritoneal macrophages into fibroblastic cells. Parasitol. Res., 1982, 76, 150-161.

Jams S. L. : Induction of protective immunity against Schistosoma mansoni by a nonliving vaccine. III. Correlation of resistance with induction of activated larvicidal macropahges. $J$. Immunol. 1986, 136, 3872-3877.

James S. L., Claven J. A. : Effects of inhibitors of tumoricidal activity upon schistosomulum killing by activated macrophages. Infect. Immun., 1987, 55, 3174-3180.

Kassis A., Aikawa M., Mahmoud A. A. F. : Mouse antibodydependent eosinophil and macrophage adherence and damage to schistosomula of Schistosoma mansoni. J. Immunol., 1979, 122, 398-405.

Malkin R., Flescher E., Lengy J., Kaisari Y. : On the interactions between macrophages and developmental stages of Schistosoma mansoni: the cytotoxic mechanisms involved in macrophagemediated killing of schistosomula in vitro. Immunology, 1987, 176, 63-72.

Melro M. C. F., Mariano M. : Extra-tissular Schistosoma mansoni egg granulomata in the peritoneal cavity at mice. Mem. Inst. Oswaldo Cruz, Rio de Janeiro, 1987, 82 (suppl.), 245-252.

Murch A. R., Grounds M. D., Marshall C. A., Papadimitriou J. M. : Direct evidence that inflammatory multinucleated giant cells form by fusion. J. Pathol., 1982, 137, 177-180.

Olds G. R., Ellner J. J., Kearse L. A. Jr., Kasura J. W., Mahmoud A. A. F. : Role of arginase in killing of Schistosomula of Schistosoma mansoni. J. Exp. Med., 1980, 151, 1557-1562.

Papadimitriou J. M., Ashman R. B. : Macrophages: Current views on their differentiation, structure and function. Ultrastr. Pathol., 1989, 13, 343-372.

Papadimitriou J. M., Robertson T. A., Walters M. N. : An analysis of the phagocytic potential of multinucleate foreign body giant cells. Am. J. Pathol., 1975, 78, 343-358.

Phillips S. M., Lammie P. : Immunopathology of granuloma formation and fibrosis in schistosomiasis. Parasitol. Today, 1986, 2, 296-302.

Postlethwaite A. E., Jackson B. K., Beachey E. H., Kang A. H. : Formation of multinucleated giant cells from monocytes precursors. Mediation by a soluble protein from antigen- and mitogen-stimulated lymphocytes. J. Exp. Med., 1982, 155, 168-178.

Skameen E., James S. L., Meltzer M. S. : Genetic control of macrophage activation for killing of extracellular targets. J. Leukocyte Biol., 1984, 35, 65-72.

Smith M. D. : The ultrastructural development of the schistosome egg granuloma in mice. Parasitol., 1977, 75, 119-123.

Von Lichtenberg F. : Studies on granuloma formation. III. Antigen sequestration and destruction in the schistosoma pseudotubercle. Am. J. Pathol., 1964, 45, 75-87. 